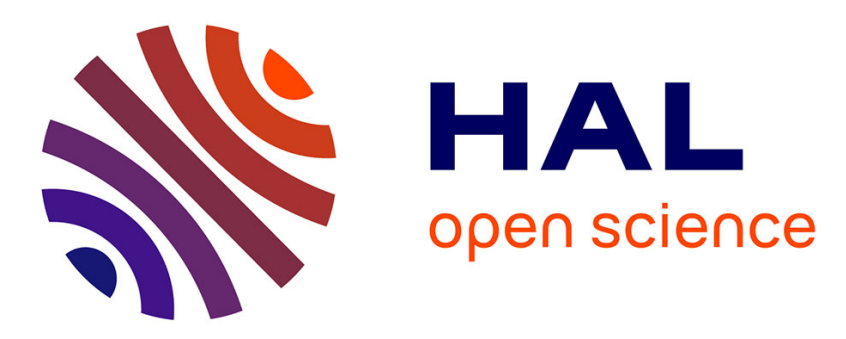

\title{
Paecilosetin derivatives as potent antimicrobial agents from Isaria farinosa
}

Orianne Brel, Seinde Toure, Marceau Levasseur, Christian Lechat, Léonie Pellissier, Jean-Luc Wolfender, Elsa van Eslande, Marc Litaudon, Isabelle Dusfour, D. Stien, et al.

\section{To cite this version:}

Orianne Brel, Seinde Toure, Marceau Levasseur, Christian Lechat, Léonie Pellissier, et al.. Paecilosetin derivatives as potent antimicrobial agents from Isaria farinosa. Journal of Natural Products, 2020, 83 (10), pp.2915-2922. 10.1021/acs.jnatprod.0c00444 . hal-03133491

\section{HAL Id: hal-03133491 https://hal.science/hal-03133491}

Submitted on 27 Feb 2023

HAL is a multi-disciplinary open access archive for the deposit and dissemination of scientific research documents, whether they are published or not. The documents may come from teaching and research institutions in France or abroad, or from public or private research centers.
L'archive ouverte pluridisciplinaire HAL, est destinée au dépôt et à la diffusion de documents scientifiques de niveau recherche, publiés ou non, émanant des établissements d'enseignement et de recherche français ou étrangers, des laboratoires publics ou privés. 


\section{Paecilosetin Derivatives as Potent Antimicrobial}

\section{Agents from Isaria farinosa}

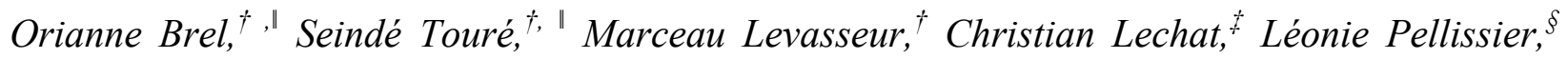

Jean-Luc Wolfender,,$^{\S}$ Elsa Van-Elslande,,$^{\dagger}$ Marc Litaudon, ${ }^{\dagger}$ Isabelle Dusfour, , Didier Stien, ${ }^{\perp}$ Véronique Eparvier ${ }^{\dagger,}$ *

†Université Paris-Saclay, CNRS, Institut de Chimie des Substances Naturelles, UPR 2301, 91198, Gif-sur-Yvette, France

${ }^{\ddagger}$ ASCOFrance, 79360, Villiers-en-bois, France

${ }^{\S}$ School of Pharmaceutical Sciences, Institute of Pharmaceutical Sciences of Western Switzerland, IPSWS, University of Geneva, CMU, 1211 Geneva 4, Switzerland

^Institut Pasteur de la Guyane, Unité de Contrôle et Adaptation des Vecteurs, BP6010, 97306

Cayenne, France; Institut Pasteur, département de Santé Globale, 75015, Paris, France

${ }^{\perp}$ Sorbonne Universités, UPMC Univ. Paris 06, CNRS, Laboratoire de Biodiversité et Biotechnologies Microbiennes (LBBM), Observatoire Océanologique, 66650 Banyuls-sur-Mer, France 


\begin{abstract}
A screening of 57 entomopathogenic microorganisms against human pathogens was subjected to mass spectrometry molecular networking-based dereplication. A particular strain of fungus, Isaria farinosa BSNB-1250, producing potentially both active and novel metabolites, was grown on a large-scale on potato dextrose agar (PDA) medium. Paecilosetin (1) and five new analogues (2-6) were isolated. The structures of the new compounds were elucidated using 1D and 2D NMR. The absolute configurations of compounds 1-6 were determined by Mosher ester derivatives (1), comparison of experimental and calculated ECD spectra (2-4 and 6), and singlecrystal X-ray diffraction analysis (5). Compounds 1-6 were assayed against methicillin-sensitive (MSSA) and methicillin-resistant Staphylococcus aureus (MRSA), Escherichia coli, Candida albicans, Trichophyton rubrum and the MRC-5 cell line. Compounds $\mathbf{1}$ and $\mathbf{5}$ exhibited strong antibacterial activity against MSSA and MRSA with MIC values of $1-2 \mu \mathrm{g} / \mathrm{mL}$.
\end{abstract}


The development of novel antimicrobial agents is urgently needed as drug-resistant pathogenic microorganisms become a major public health problem. ${ }^{1}$ Natural products are a historical source of valuable antimicrobials and still offer significant potential for the discovery of novel antibacterial and antifungal therapies. ${ }^{2}$ Microbes largely contribute to the chemodiversity of natural products owing to their diversity and ubiquitous occurrence. ${ }^{3,45}$ In addition, they have the advantage of being a renewable source, as they can be cultured in the laboratory and scaled up as required. Entomopathogenic microorganisms, the natural enemies of insects, are known to provide bioactive metabolites implicated in complex defense mechanisms. ${ }^{6}$ Since they must control the defensive barriers of their host and other microorganisms that colonize insects, they produce many compounds, including antibiotics and antifungals. However, time-consuming purifications and rediscovery of known compounds are a recurring problem. Mass spectrometrybased molecular networking approaches can be used to overcome these difficulties, allowing the targeting of specific metabolites through the tandem mass spectrometry datasets organization they confer. ${ }^{7-11}$

Fifty-seven bacterial and fungal isolates from living infected insect cuticle have been screened against several human pathogenic microorganisms. In parallel, the collection was analyzed by high-resolution tandem mass spectrometry profiling (HRMS/MS), and the combined data were organized into molecular networks (MNs). As a result, an Isaria farinosa BSNB-1250 ethyl acetate (EtOAc) extract exhibited interesting antimicrobial activities and potentially new metabolites. The strain was thus selected for further investigations. Fungi belonging to the genus Isaria are known to infect insects belonging to the orders Homoptera, Lepidoptera and Coleoptera. ${ }^{12}$ They have been the source of a wide array of metabolites of different chemical classes and diverse biological activities. Among them, antimicrobial compounds such as 
hydroxypyridinone and tetramic acid derivatives, ${ }^{13,14}$ cytotoxic cycloaspeptides $\mathrm{C}, \mathrm{F}$ and $\mathrm{G},{ }^{15}$ and the antioxidant pseudodipeptide hanasanagin have been reported from diverse Isaria spp. ${ }^{16}$

Large-scale cultivation on potato dextrose agar (PDA) medium, fractionation, and molecular networking attached to biological activities allowed six decanoyl tetramic acids to be isolated. To optimize metabolite production and/or increase chemical diversity, diverse culture conditions were tested. ${ }^{17-19}$ Indeed, it has been established that microbial chemical diversity is often largely underestimated under standard culture conditions. ${ }^{20-22}$ Small changes in culture conditions or cocultivation with other microbial species may activate cryptic biosynthetic pathways. ${ }^{23-25}$ Therefore, to analyze substantial subsequent production of the metabolites identified, the fungal strain was cultivated on seven different culture media.

\section{RESULTS AND DISCUSSION}

As shown in the previous study of Toure et al. ${ }^{10} 57$ microorganisms isolated from diverse insect cuticles were cultivated on a small-scale (10 Petri dishes) on PDA medium. Extracts were obtained by maceration in EtOAc, and screened for activity against methicillin-sensitive and methicillin-resistant Staphylococcus aureus (MSSA and MRSA), Candida albicans, and Trichophyton rubrum. The extracts were also analyzed by ultrahigh-performance liquid chromatography-high-resolution mass spectrometry (UHPLC-HRMS/MS) using the datadependent acquisition mode.

MZmine ${ }^{8,26}$ was used to process the data and $\mathrm{MetGem}^{9}$ to calculate and visualize a single molecular network (Figure 1 and Supporting Information S1). A molecular network with 9007 nodes was obtained. Each nodes is represented by pie charts showing relative quantification of the ions, based on the respective areas of the corresponding extracted ion chromatograph (XIC). 
Activity against human pathogens can then be mapped on this molecular network. ${ }^{27}$ Each strain with a minimal inhibitory concentration equal or better than $64 \mu \mathrm{g} / \mathrm{mL}$ is represented with a single color, while the other strains are colored in gray.

The Isaria farinosa strain showed both interesting MIC values $(32-64 \mu \mathrm{g} / \mathrm{mL})$ and unique clusters in the molecular network. One particular cluster showed $\mathrm{MS}^{2}$ spectra libraries matches as analogues of decanoyl tetramic acids (Figure 1). According to their $m / z$ value, the three nodes of this cluster at $\mathrm{m} / \mathrm{z} 374.233$ correspond to paecilosetin, first isolated by Lang et al. ${ }^{14}$ It was then assumed that several new analogues of paecilosetin could be isolated from this fungus.

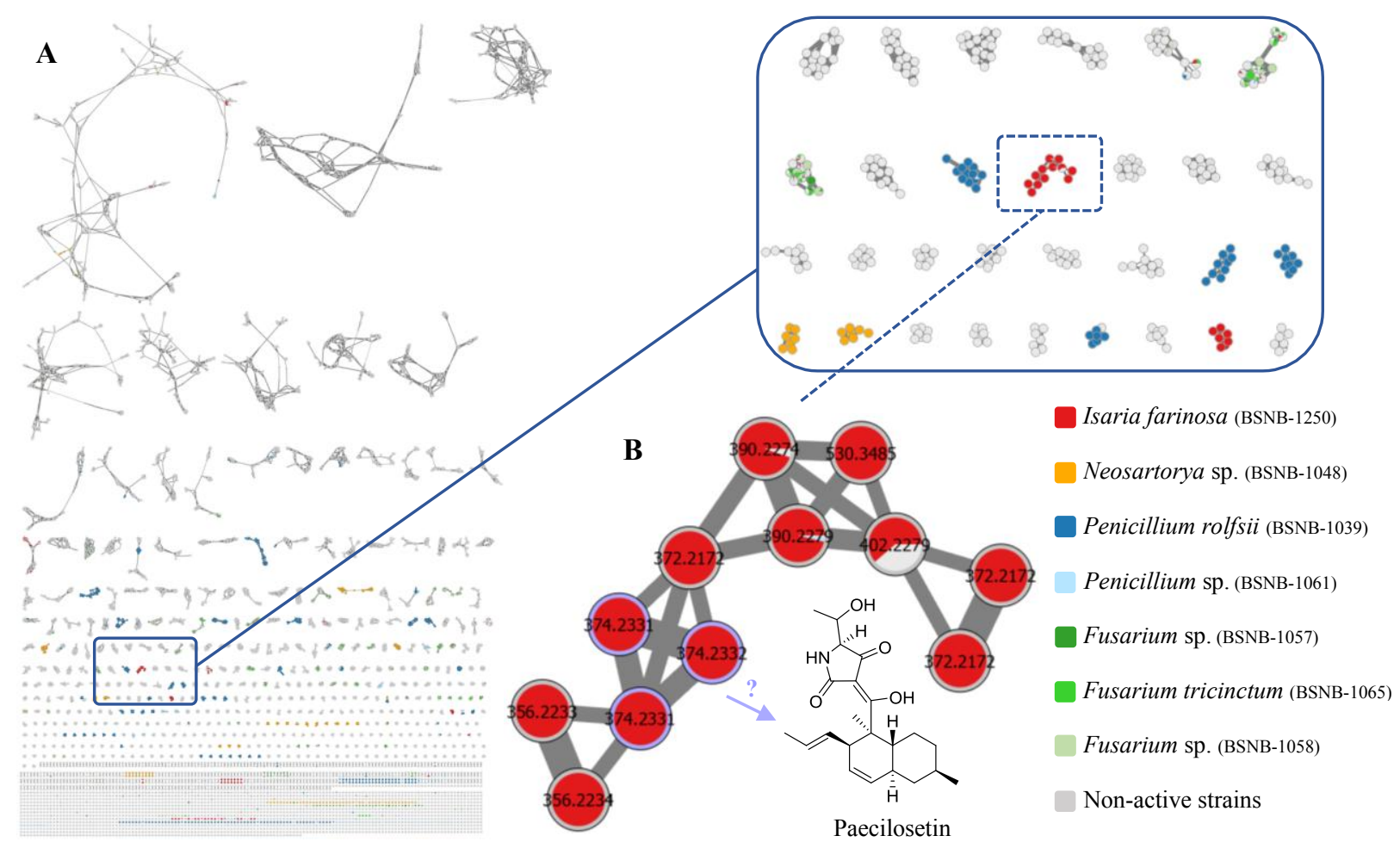

Figure 1. (A) Global molecular network with detection of bioactive clusters by mapping MRSA activity. Only ions from strains with significant antimicrobial activity (MIC $<64 \mu \mathrm{g} / \mathrm{mL}$ ) are highlighted with color tags; gray tags are used for non-active strains. (B) Decanoyl tetramic acid cluster. One of the ions circled in purple may correspond to the protonated ion of paecilosetin. 
Based on these results, isolation of putative tetramic acid derivatives was undertaken from a large-scale culture of I. farinosa on PDA medium, leading to paecilosetin A (1) and five new paecilosetin analogues (2-6).

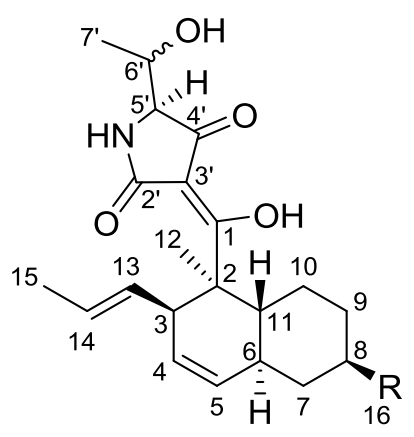

$16^{\prime}(S), \mathrm{R}=\mathrm{CH}_{3}$

$26^{\prime}(R), \mathrm{R}=\mathrm{CH}_{3}$

$36^{\prime}(S), \mathrm{R}=\mathrm{CH}_{2} \mathrm{OH}$

$46^{\prime}(R), \mathrm{R}=\mathrm{CH}_{2} \mathrm{OH}$

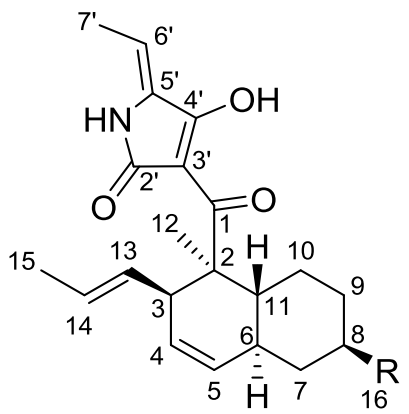

$5 \mathrm{R}=\mathrm{CH}_{3}$

$6 \mathrm{R}=\mathrm{CH}_{2} \mathrm{OH}$

Compound 1 was isolated as a yellow solid. A molecular formula of $\mathrm{C}_{22} \mathrm{H}_{31} \mathrm{NO}_{4}$ was determined based on HRESIMS analysis. MS analysis and evaluation of NMR data suggested that compound 1 was paecilosetin (Table 2), previously isolated from Paecilomyces farinosus (syn. I. farinosa $)^{12}$ found on an infected insect larva in New Zealand. ${ }^{14}{ }^{1} \mathrm{H}-{ }^{1} \mathrm{H}$ NOE correlations confirmed that the relative configuration of the decaline subunit was identical to equisetin and trichosetin (Figure 2 and Figure 3$)^{28-32}$ and indicated a $\left(2 S^{*}, 3 R^{*}, 6 S^{*}, 8 R^{*}, 11 R^{*}\right)$ relative configuration. The specific negative optical rotation data were also similar to the ones given in the literature. ${ }^{14}$ As described previously for this class of compounds, the two negative Cotton effects at 239 and $284 \mathrm{~nm}$ for compound 1 suggest an $S$-configuration at C-5' (Supporting Information S3). ${ }^{28-32}$ Consequently, it was assumed that compound 1 had a $2 S, 5$ ' $S$ configuration. The configuration in C-6' cannot be determined by ECD and has never been described before. $(S)$ - and $(R)$-MTPA esters of compound $\mathbf{1}$ were therefore synthetized (respectively $\mathbf{1 a}$ and $\mathbf{1 b}$, Figure 4 and Supporting Information S15 to S18). The chemical shift differences between hydrogens H-5' (+0.49) and H-7' (-0.04) in $\mathbf{1 a}$ and $\mathbf{1 b}$ allowed the relative configuration of C-6' to be assigned as $S$ for compound $1 .^{33}$ Consequently, this compound was assigned as $2 S, 3 R, 6 S, 8 R, 11 R, 5^{\prime} S, 6^{\prime} S$ and was named paecilosetin A. 


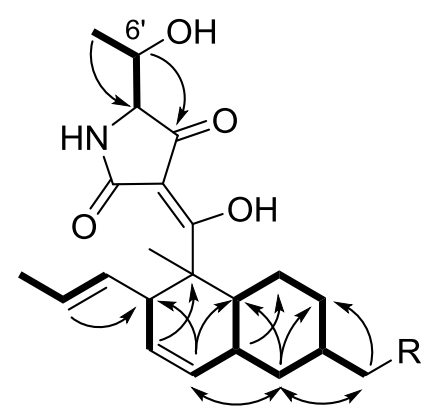

$16^{\prime}(S), \mathrm{R}=\mathrm{H}$

$36^{\prime}(S), \mathrm{R}=\mathrm{OH}$

$46^{\prime}(R), \mathrm{R}=\mathrm{OH}$

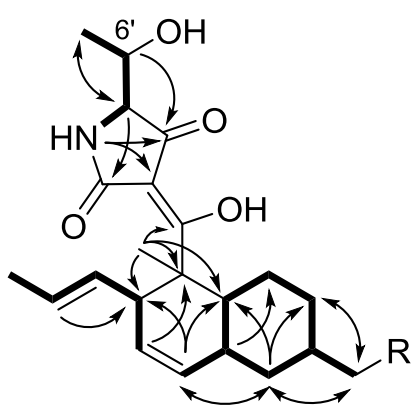

$26^{\prime}(R), \mathrm{R}=\mathrm{H}$

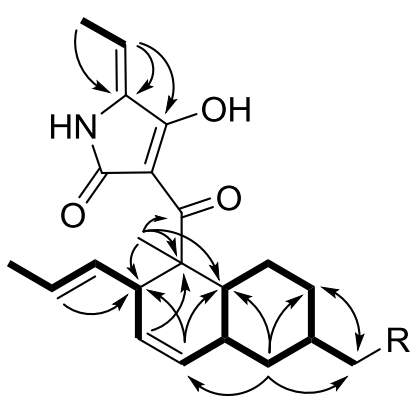

$5 \mathrm{R}=\mathrm{H}$

$6 \mathrm{R}=\mathrm{OH}$

Figure 2. Key ${ }^{1} \mathrm{H}_{-}{ }^{1} \mathrm{H}$ COSY (bold bonds) and ${ }^{1} \mathrm{H}_{-}{ }^{13} \mathrm{C}$ (plain arrow) correlations of $\mathbf{1}-\mathbf{6}$.

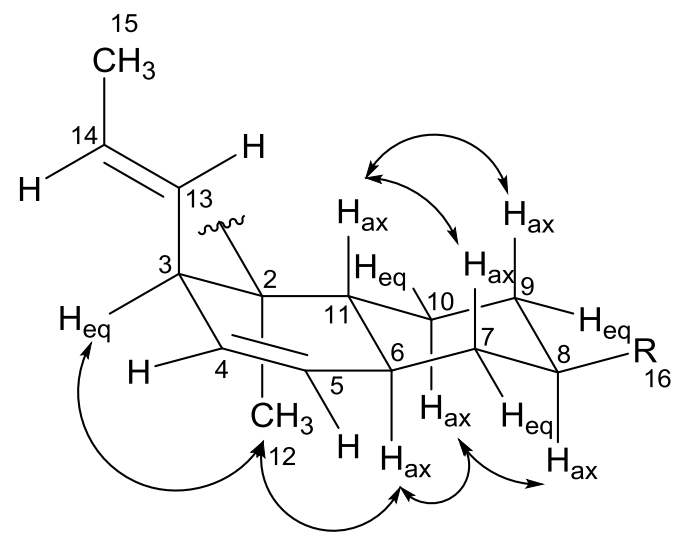

1,2,5 $\mathrm{R}=\mathrm{CH}_{3}$

3,4,6 $\mathrm{R}=\mathrm{CH}_{2} \mathrm{OH}$

Figure 3. Key NOESY correlations of compounds 1-6 decaline moiety.

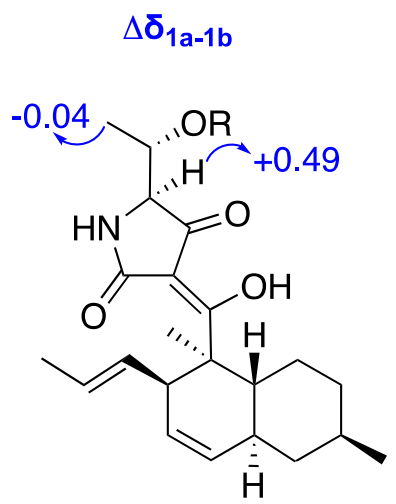

1a $\mathrm{R}=(S)-M T P A$

1b $\mathrm{R}=(R)$-MTPA
$\Delta \bar{\delta}_{3 a-3 b}$

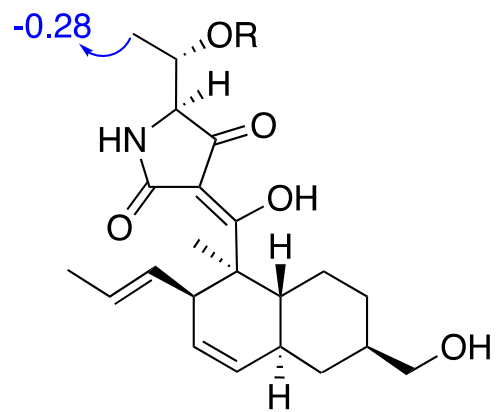

3a $\mathrm{R}=(S)$-MTPA

3b $\mathrm{R}=(R)$-MTPA
$\Delta \delta_{4 a-4 b}$

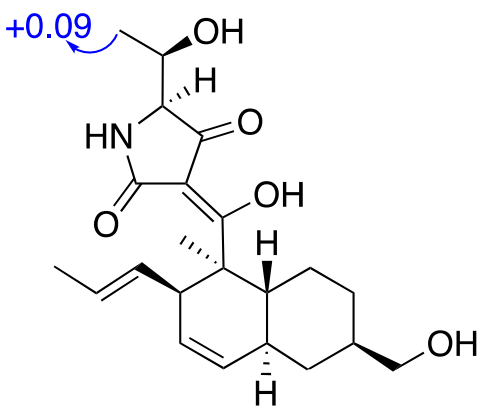

4a $\mathrm{R}=(S)$-MTPA

4b $\mathrm{R}=(R)$-MTPA

Figure 4. Chemical shift differences between the $(S)$-MTPA and $(R)$-MTPA esters of 1, 3 and 4. 
Compound $\mathbf{2}$ was isolated as a yellow solid and showed the same molecular formula as $\mathbf{1}$. In comparison with 1, ${ }^{1} \mathrm{H}$ NMR data of compound 2 showed differences at H-5' (at 3.78 ppm instead of 3.69 for $\mathbf{1}$ ) and H-7' (1.18 ppm instead of 1.32 for $\mathbf{1})$. The ${ }^{13} \mathrm{C} N M R$ data showed significant shift differences for C-6' and C-7' (Table 2). The 2D NMR spectra (COSY, HMBC, NOESY) were also very similar (Supporting Information S26 to S28). ${ }^{1} \mathrm{H}-{ }^{1} \mathrm{H}$ NOE correlations confirmed that the relative configuration was identical in the decaline moiety. For example, correlations $\mathrm{H}-8 / \mathrm{H}-10, \mathrm{H} 10-\mathrm{H} 6, \mathrm{H}-6 / \mathrm{H}-12$ and H12-H3 indicated that these protons are on the same face of the decaline (Figure 3). Altogether, these data suggested that $\mathbf{1}$ and $\mathbf{2}$ are diastereoisomers in C-5' and/or C-6'. The absolute configuration of $\mathbf{2}$ was determined by the comparison of CD spectrum with that from 1, suggesting an S-configuration at C-2 and C-5' similar to in $\mathbf{1}$ (Supporting Information S3 and S20) and by comparison with literature data (see $\mathrm{S} 32$ and S33). Consequently, it has been assumed that the absolute configuration should be $R$ in C-6'. Hence, compound 2 was assigned as $2 S, 3 R, 6 S, 8 R, 11 R, 5^{\prime} S, 6^{\prime} R$. This compound was named 6'-epi-paecilosetin A. When comparing H-7' and C-7' chemical shifts of compounds 1 and 2 with the paecilosetin described by Lang et al., ${ }^{14}$ it can be deduced that paecilosetin A corresponds to their description.

Compounds 3 and $\mathbf{4}$, isolated as yellow solids, exhibited a protonated molecular ion peak at respectively $m / z 390.2292[\mathrm{M}+\mathrm{H}]^{+}$and $m / z 390.2280[\mathrm{M}+\mathrm{H}]^{+}$(calculated for $\mathrm{C}_{22} \mathrm{H}_{32} \mathrm{NO}_{5}$, 390.2280) corresponding to eight indices of hydrogen deficiency. Except for the methyl in C-16, the ${ }^{1} \mathrm{H}$ and ${ }^{13} \mathrm{C}$ NMR data (Table 2) of $\mathbf{3}$ and $\mathbf{4}$ were similar to those of $\mathbf{1}$ and $2 .{ }^{1} \mathrm{H}-{ }^{1} \mathrm{H}$ COSY correlations between $\mathrm{H}-8$ and $\mathrm{H}-16$, and $\mathrm{a}{ }^{1} \mathrm{H}_{-}{ }^{13} \mathrm{C}$ HMBC correlation of $\mathrm{H}-16$ with $\mathrm{C}-7$, combined with the integration of H-16 corresponding to two hydrogens and their chemical shift (3.48 ppm (3) and 3.49 (4) for H-16, 68.5 ppm for C-16 (3 and 4), demonstrated that C-16 was 
hydroxylated. Eventually, the relative and absolute configurations of $\mathbf{3}$ were found to be the same as in $\mathbf{1}$ by comparison of 1D and 2D NMRs, and CD data (Table 2 and Supporting Information S35 to S43), including 6' $(S)$ configuration (by comparison of ${ }^{1} \mathrm{H}$ and ${ }^{13} \mathrm{C}$ chemical shifts on positions $\mathrm{C}-5^{\prime}$, and $\left.\mathrm{C}-7^{\prime}\right)$.

Therefore, the designation $2 S, 3 R, 6 S, 8 R, 11 R, 5^{\prime} S, 6^{\prime} S$ was proposed for compound $\mathbf{3}$, which was named paecilosetin B. In the same way, comparison of 1D and 2D NMRs and CD data of compounds $\mathbf{2}$ and $\mathbf{4}$ confirmed their identical relative and absolute configurations (Table 2 and Supporting Information S49 to S57). Compounds $\mathbf{3}$ and $\mathbf{4}$ are thus 6'-epimers as with $\mathbf{1}$ and $\mathbf{2}$. From these observations, compound $\mathbf{4}$ was identified as 6'-epi-paecilosetin $\mathrm{B}$, and the $2 S, 3 R, 6 S, 8 R, 11 R, 5^{\prime} S, 6^{\prime} R$ absolute configuration was assigned. More evidence is given by analysis of the Mosher esters of compounds 3 and 4. In 3, a negative chemical shift between $S$ MTPA and $R$-MTPA esters on H-6' indicated a 6' $S$ configuration, while a positive chemical shift between $S$-MTPA and $R$-MTPA esters of 4 spoke out for a $6^{\prime} R$ configuration.

Compound 5, colorless needles, showed a protonated molecular ion peak at $m / z 356.2234$ $[\mathrm{M}+\mathrm{H}]^{+}$(calculated for $\mathrm{C}_{22} \mathrm{H}_{30} \mathrm{NO}_{3}, 356.2226$ ) indicating nine indices of hydrogen deficiency. The ${ }^{1} \mathrm{H}$ and ${ }^{13} \mathrm{C}$ NMR data (Table 2) of $\mathbf{5}$ were similar to those of $\mathbf{1}$ and $\mathbf{2}$ for the decalin moiety. Regarding the tetramic acid moiety, two main differences between compound 5 and the latter can be identified. The first is the presence of a C5'-C6' olefin moiety, confirmed by the low-field shifts of C-5' $\left(\delta_{\mathrm{C}} 132.6 \mathrm{ppm}\right)$ and $\mathrm{CH}-6^{\prime}\left(\delta_{\mathrm{H}} / \delta_{\mathrm{C}} 5.88 / 110.2 \mathrm{ppm}\right)$ (Supporting Information S66 to S73). A $Z$ configuration for this olefin is supported by a NOE correlation between $\mathrm{H}-1$ ' and H-7'. The second concerns NMR chemical shift differences for the tetramic moiety, which can be explained by the planar conjugated system (Table 2). The relative and absolute configurations of the decalin moiety of $\mathbf{5}$ and $\mathbf{6}$ were found to be identical to those of $\mathbf{1}$ on the basis of 2D NOESY 
spectrum and ECD data analysis (Supporting Information S65 and S72). They were confirmed by X-ray diffraction analysis (Figure 5 and Supporting Information S85). Thus, the absolute configuration of compound $\mathbf{5}$, named paecilosetin $\mathrm{C}$, was assigned as $2 S, 3 R, 6 S, 8 R, 11 R$.

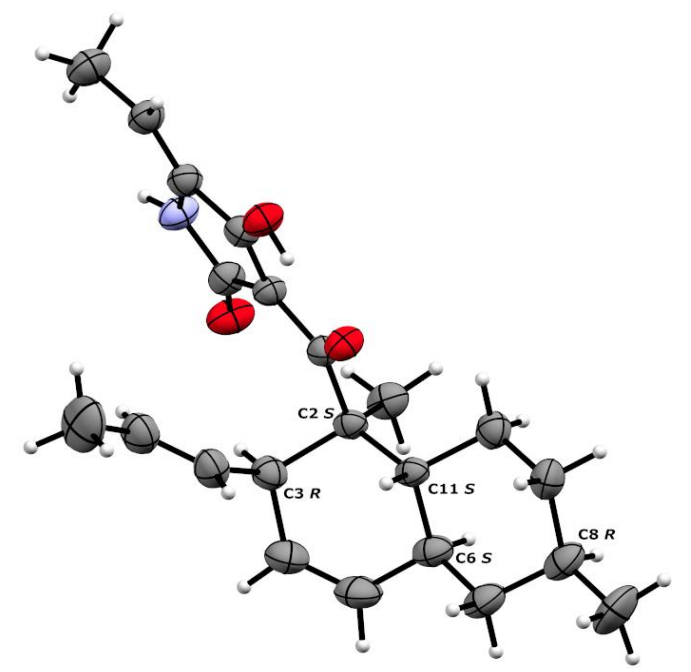

Figure 5. ORTEP view of the X-ray structure of compound 5.

The elemental composition of compound $\mathbf{6}$, a pale pink solid, was determined to be $\mathrm{C}_{22} \mathrm{H}_{29} \mathrm{NO}_{4}$ (nine indices of hydrogen deficiency) by HRESIMS analysis. ${ }^{1} \mathrm{H}$ and ${ }^{13} \mathrm{C}$ NMR spectroscopic data of compound $\mathbf{6}$ were similar to those of compound $\mathbf{5}$, with the presence of a $\mathrm{CH}_{2} \mathrm{OH}$ group at C-8 in $\mathbf{6}$ instead of a methyl group (Table 2). Corroborating correlations can be observed between $\mathrm{H}-8$ and $\mathrm{H}-16$ on the ${ }^{1} \mathrm{H}-{ }^{1} \mathrm{H}$ COSY experiment and between $\mathrm{H}-16$ and $\mathrm{C}-7$ on the ${ }^{1} \mathrm{H}-{ }^{13} \mathrm{C}$ HMBC. Analysis of ECD and 2D NMR spectroscopic data established the same relative and absolute configurations as compound 5 (Supporting Information S75 to S83). Thus, the absolute configuration of compound $\mathbf{6}$, paecilosetin $\mathrm{D}$, was assigned as $2 S, 3 R, 6 S, 8 R, 11 R$.

Compounds 1, 2 and $\mathbf{5}$ showed potent antimicrobial activities against human pathogens MSSA and MRSA with MIC values of 1-16 $\mu \mathrm{g} / \mathrm{mL}$, and weak cytotoxic activities against MRC-5 
(Table 1). Since compounds $\mathbf{3}, \mathbf{4}$ and $\mathbf{6}$ exhibited no or weak antimicrobial activities, it can be deduced that the presence of a hydroxy group at C-16 has a detrimental effect on the activity against these strains.

Table 1. Antimicrobial Activity of 1-6

\begin{tabular}{|c|c|c|c|c|c|c|c|}
\hline \multirow[b]{2}{*}{ strain } & \multirow[b]{2}{*}{1} & \multicolumn{4}{|c|}{ MIC values $(\mu \mathrm{g} / \mathrm{mL})$} & \multirow[b]{2}{*}{6} & \multirow[b]{2}{*}{$\begin{array}{l}\text { pos. } \\
\text { ctrl. }^{c}\end{array}$} \\
\hline & & 2 & $\overline{3}$ & 4 & 5 & & \\
\hline $\begin{array}{l}\text { MSSA }^{a} \\
\text { (ATC29213) }\end{array}$ & 2 & 8 & $>256$ & $>256$ & 2 & 64 & 0.25 \\
\hline $\begin{array}{l}\text { MRSA }^{b} \\
\text { (ATCC33591) }\end{array}$ & 2 & 16 & $>256$ & $>256$ & 1 & 128 & 4 \\
\hline $\begin{array}{l}\text { C. albicans } \\
\text { (ATCC10231) }\end{array}$ & 16 & 128 & $>256$ & $>256$ & 32 & $>256$ & 1 \\
\hline $\begin{array}{l}\text { T. rubrum } \\
\text { (SNB-TR1) }\end{array}$ & 32 & 64 & $>256$ & $>256$ & 32 & $>256$ & 4 \\
\hline $\begin{array}{l}\text { E. coli } \\
\text { (ATCC 25922) }\end{array}$ & $>256$ & $>256$ & 256 & $>256$ & $>256$ & $>256$ & 8 \\
\hline \multicolumn{8}{|c|}{$\mathrm{IC}_{50}(\mu \mathrm{M})$} \\
\hline MRC-5 & $\begin{array}{r}40 \\
+/-7.4\end{array}$ & $\begin{array}{l}50.3 \\
+/-1\end{array}$ & nd & nd & $\begin{array}{r}24.2 \\
+/-3.3\end{array}$ & $\begin{array}{r}106 \\
+/-10\end{array}$ & $\begin{array}{r}0.040+/- \\
0.0012\end{array}$ \\
\hline \multicolumn{8}{|c|}{$\begin{array}{l}{ }^{a} \text { Methicillin-sensitive Staphylococcus aureus. } \\
{ }^{b} \text { Methicillin-resistant Staphylococcus aureus. } \\
{ }^{c} \text { Positive control: oxacillin for MSSA, vancomycine for MRSA, } \\
\text { fluconazole for Candida albicans and Trichophyton rubrum, gentamicin for } \\
\text { Escherichia coli and doxorubicin for MRC-5. }\end{array}$} \\
\hline
\end{tabular}


Table 2. NMR Spectroscopic Data of 1-6 $\left(\mathrm{CDCl}_{3}\right)^{a}$

\begin{tabular}{|c|c|c|c|c|c|c|c|c|c|c|c|c|}
\hline \multicolumn{3}{|c|}{ paecilosetin A (1) } & \multicolumn{2}{|c|}{ 6'-epi-paecilosetin A (2) } & \multicolumn{2}{|c|}{ paecilosetin B (3) } & \multicolumn{2}{|c|}{ 6'-epi-paecilosetin B (4) } & \multicolumn{2}{|c|}{ paecilosetin C (5) } & \multicolumn{2}{|c|}{ paecilosetin D (6) } \\
\hline position & $\delta_{\mathrm{C}}$, type & $\delta_{\mathrm{H}}(J$ in $\mathrm{Hz})$ & $\delta_{\mathrm{C}}$, type & $\delta_{\mathrm{H}}(J$ in $\mathrm{Hz})$ & $\delta_{\mathrm{C}}$, type & $\delta_{\mathrm{H}}(J$ in $\mathrm{Hz})$ & $\delta_{\mathrm{C}}$, type & $\delta_{\mathrm{H}}(J$ in $\mathrm{Hz})$ & $\delta_{\mathrm{C}}$, type & $\delta_{\mathrm{H}}(J$ in $\mathrm{Hz})$ & $\delta_{\mathrm{C}}$, type & $\delta_{\mathrm{H}}(J$ in $\mathrm{Hz})$ \\
\hline 1 & $200.2, \mathrm{C}$ & & $201.1, \mathrm{C}$ & & $199.9, \mathrm{C}$ & & $200.9, \mathrm{C}$ & & $206.3, \mathrm{C}$ & & $206.2, \mathrm{C}$ & \\
\hline 2 & 49.0, C & & 49.1, C & & 49.0, C & & $49.2, \mathrm{C}$ & & $51.0, \mathrm{C}$ & & $51.0, \mathrm{C}^{b}$ & \\
\hline 3 & $45.2, \mathrm{CH}$ & $3.37, \mathrm{~m}$ & $45.3, \mathrm{CH}$ & $3.34, \mathrm{~m}$ & $45.1, \mathrm{CH}$ & $3.38, \mathrm{~m}$ & $45.2, \mathrm{CH}$ & $3.38, \mathrm{~m}$ & $45.1, \mathrm{CH}$ & $3.66, \mathrm{~m}$ & $45.0, \mathrm{CH}$ & $3.65, \mathrm{~m}$ \\
\hline 4 & $126.7, \mathrm{CH}$ & $5.38, \mathrm{~m}$ & $126.7, \mathrm{CH}$ & $5.38, \mathrm{~m}$ & $127.0, \mathrm{CH}$ & $5.39, \mathrm{~m}$ & $127.1, \mathrm{CH}$ & $5.39, \mathrm{~m}$ & $126.8, \mathrm{CH}$ & $5.39, \mathrm{~m}$ & $127.2, \mathrm{CH}$ & $5.41, \mathrm{~m}$ \\
\hline 5 & $130.1, \mathrm{CH}$ & $5.41, \mathrm{~m}$ & $130.1, \mathrm{CH}$ & $5.41, \mathrm{~m}$ & $129.7, \mathrm{CH}$ & $5.42, \mathrm{~m}$ & $129.7, \mathrm{CH}$ & $5.42, \mathrm{~m}$ & $130.3, \mathrm{CH}$ & $5.42, \mathrm{~m}$ & $129.8, \mathrm{CH}$ & $5.44, \mathrm{~m}$ \\
\hline 6 & $38.7, \mathrm{CH}$ & $1.85, \mathrm{~m}$ & $38.6, \mathrm{CH}$ & $1.85, \mathrm{~m}$ & $38.2, \mathrm{CH}$ & $1.86, \mathrm{~m}$ & $38.1, \mathrm{CH}$ & $1.86, \mathrm{~m}$ & $38.7, \mathrm{CH}$ & $1.84, \mathrm{~m}$ & $38.2, \mathrm{CH}$ & $1.87, \mathrm{~m}$ \\
\hline 7 & $42.4, \mathrm{CH}_{2}$ & $\begin{array}{l}1.81, \mathrm{~m} \\
0.90, \mathrm{~m}\end{array}$ & $42.4, \mathrm{CH}_{2}$ & $\begin{array}{l}1.82, \mathrm{~m} \\
0.90, \mathrm{~m}\end{array}$ & $36.6, \mathrm{CH}_{2}$ & $\begin{array}{l}1.92, \mathrm{~m} \\
0.93, \mathrm{~m}\end{array}$ & $36.6, \mathrm{CH}_{2}$ & $\begin{array}{l}1.93, \mathrm{~m} \\
0.94, \mathrm{~m}\end{array}$ & $42.5, \mathrm{CH}$ & $\begin{array}{l}1.82, \mathrm{~m} \\
0.90, \mathrm{~m}\end{array}$ & $36.7, \mathrm{CH}_{2}$ & $\begin{array}{l}1.95, \mathrm{~m} \\
0.95, \mathrm{~m}\end{array}$ \\
\hline 8 & $33.6, \mathrm{CH}$ & $1.51, \mathrm{~m}$ & $33.6, \mathrm{CH}$ & $1.51, \mathrm{~m}$ & $41.2, \mathrm{CH}$ & $1.65, \mathrm{~m}$ & $41.2, \mathrm{CH}$ & $1.66 \mathrm{~m}$ & $33.7, \mathrm{CH}$ & $1.51, \mathrm{~m}$ & $41.3, \mathrm{CH}$ & $1.66, \mathrm{~m}$ \\
\hline 9 & $35.8, \mathrm{CH}_{2}$ & $\begin{array}{l}1.76, \mathrm{~m} \\
1.12, \mathrm{~m}\end{array}$ & $35.8, \mathrm{CH}_{2}$ & $\begin{array}{l}1.77, \mathrm{~m} \\
1.12 \mathrm{~m}\end{array}$ & $30.0, \mathrm{CH}_{2}$ & $\begin{array}{l}1.85, \mathrm{~m} \\
1.15, \mathrm{~m}\end{array}$ & 29.9, $\mathrm{CH}_{2}$ & $\begin{array}{l}1.88, \mathrm{~m} \\
1.16, \mathrm{~m}\end{array}$ & $35.9, \mathrm{CH}_{2}$ & $\begin{array}{l}1.77, \mathrm{~m} \\
1.14, \mathrm{~m}\end{array}$ & $30.0, \mathrm{CH}_{2}$ & $\begin{array}{l}1.86, \mathrm{~m} \\
1.19, \mathrm{~m}\end{array}$ \\
\hline 10 & $28.5, \mathrm{CH}_{2}$ & $\begin{array}{l}1.96, \mathrm{~m} \\
1.05, \mathrm{~m}\end{array}$ & $28.5, \mathrm{CH}_{2}$ & $\begin{array}{l}1.95, \mathrm{~m} \\
1.06, \mathrm{~m}\end{array}$ & 27.9, $\mathrm{CH}_{2}$ & $\begin{array}{l}2.04, \mathrm{~m} \\
1.06, \mathrm{~m}\end{array}$ & 27.9, $\mathrm{CH}_{2}$ & $\begin{array}{l}2.04, \mathrm{~m} \\
1.07, \mathrm{~m}\end{array}$ & 28.0, $\mathrm{CH}_{2}$ & $\begin{array}{l}2.01, \mathrm{~m} \\
1.01, \mathrm{~m}\end{array}$ & 27.5, $\mathrm{CH}_{2}$ & $\begin{array}{l}2.08, \mathrm{~m} \\
1.05, \mathrm{~m}\end{array}$ \\
\hline 11 & $40.1, \mathrm{CH}$ & $1.68, \mathrm{~m}$ & $40.1, \mathrm{CH}$ & $1.69, \mathrm{~m}$ & $40.4, \mathrm{CH}$ & $1.70, \mathrm{~m}$ & $40.4, \mathrm{CH}$ & $1.71, \mathrm{~m}$ & $40.3, \mathrm{CH}$ & $1.67 \mathrm{~m}$ & $40.5, \mathrm{CH}$ & $1.71, \mathrm{~m}$ \\
\hline 12 & $14.1, \mathrm{CH}_{3}$ & $1.46, \mathrm{~m}$ & $14.0, \mathrm{CH}_{3}$ & $1.47, \mathrm{~m}$ & $14.0, \mathrm{CH}_{3}$ & $1.46, \mathrm{~m}$ & $14.7, \mathrm{CH}_{3}$ & $1.47, \mathrm{~m}$ & $14.4, \mathrm{CH}_{3}$ & $1.50, \mathrm{~m}$ & $14.3, \mathrm{CH}_{3}$ & $1.50, \mathrm{~m}$ \\
\hline 13 & $131.0, \mathrm{CH}$ & $5.17, \mathrm{~m}$ & 131.0, CH & $5.17, \mathrm{~m}$ & $130.9, \mathrm{CH}$ & $5.16, \mathrm{~m}$ & $130.8, \mathrm{CH}$ & $5.15, \mathrm{~m}$ & $131.3, \mathrm{CH}$ & $5.15, \mathrm{~m}$ & $131.1, \mathrm{CH}$ & $5.15, \mathrm{~m}$ \\
\hline 14 & $127.3, \mathrm{CH}$ & $5.27, \mathrm{~m}$ & $127.0, \mathrm{CH}$ & $5.25, \mathrm{~m}$ & $127.5, \mathrm{CH}$ & $5.26, \mathrm{~m}$ & $127.2, \mathrm{CH}$ & $5.26, \mathrm{~m}$ & $127.3, \mathrm{CH}$ & $5.31, \mathrm{~m}$ & $127.4, \mathrm{CH}$ & $5.31, \mathrm{~m}$ \\
\hline 15 & $18.0, \mathrm{CH}_{3}$ & $1.53, \mathrm{~m}$ & $17.9, \mathrm{CH}_{3}$ & $1.52, \mathrm{~d}(5.4)$ & $18.0, \mathrm{CH}_{3}$ & $1.51, \mathrm{~m}$ & $17.8, \mathrm{CH}_{3}$ & $1.51, \mathrm{~d}(5.4)$ & $18.1, \mathrm{CH}_{3}$ & $1.52, \mathrm{~m}$ & $18.1, \mathrm{CH}_{3}$ & $1.51, \mathrm{~m}$ \\
\hline 16 & $22.6, \mathrm{CH}_{3}$ & $0.92, d(6.5)$ & $22.6, \mathrm{CH}_{3}$ & $0.92, \mathrm{~d}(6.5)$ & $68.5, \mathrm{CH}_{2}$ & $3.48, \mathrm{~d}(6.2)$ & $68.5, \mathrm{CH}_{2}$ & $3.49, \mathrm{~d}(6.2)$ & $22.7, \mathrm{CH}_{3}$ & $0.92, d(6.4)$ & 68.6, $\mathrm{CH}_{2}$ & $3.50, \mathrm{~m}$ \\
\hline 2 ' & $179.6, \mathrm{C}$ & & $179.5, \mathrm{C}$ & & $179.6, \mathrm{C}$ & & $179.5, \mathrm{C}$ & & 167.7, C & & 167.2, C & \\
\hline 3 ' & 100.6, C & & $100.2, \mathrm{C}$ & & 100.6, C & & 100.2, C & & 105.2, C & & nd & \\
\hline 4, & 191.2, C & & $191.9, \mathrm{C}$ & & 191.3, C & & 191.7, C & & $180.8, \mathrm{C}$ & & $180.7, \mathrm{C}$ & \\
\hline 5, & $65.8, \mathrm{CH}$ & $3.69, \mathrm{~m}$ & $65.0, \mathrm{CH}$ & $3.78, \mathrm{~m}$ & $66.0, \mathrm{CH}$ & $3.67, \mathrm{~m}$ & $65.1, \mathrm{CH}$ & $3.82, \mathrm{~m}$ & 132.6, C & & $132.5, \mathrm{C}^{b}$ & \\
\hline 6 ' & $67.8, \mathrm{CH}$ & $4.07, \mathrm{~m}$ & $68.5, \mathrm{CH}$ & $4.05, \mathrm{~m}$ & $67.7, \mathrm{CH}$ & $4.06, \mathrm{~m}$ & $68.4, \mathrm{CH}$ & $4.07, \mathrm{~m}$ & $110.2, \mathrm{CH}$ & $5.88, \mathrm{q}(7.5)$ & $109.8, \mathrm{CH}$ & $5.87, \mathrm{q}(7.5)$ \\
\hline 7 & $19.7, \mathrm{CH}_{3}$ & $1.32, \mathrm{~d}(6.1)$ & $18.1, \mathrm{CH}_{3}$ & $1.18, \mathrm{~d}(5.9)$ & $19.8, \mathrm{CH}_{3}$ & $1.32, \mathrm{~d}(5.9)$ & 17.9, $\mathrm{CH}_{3}$ & $1.16, \mathrm{~d}(5.8)$ & $12.7, \mathrm{CH}_{3}$ & $1.94, \mathrm{~d}(7.5)$ & $12.7, \mathrm{CH}_{3}$ & $1.89, \mathrm{~m}$ \\
\hline $\mathrm{NH}$ & & 6.77, brs & & 6.67, brs & & 7.06, brs & & 6.81, brs & & 9.16, brs & & 8.45, brs \\
\hline
\end{tabular}


A metabolomic profiling and a differential analysis of $I$. farinosa extracts produced with different culture conditions was also conducted (S86). Biological activities of each extracts obtained were consistent with the distribution of the metabolites observed in the previous molecular network (Supporting Information S87). Extract obtained from malt medium culture displayed the strongest MIC values against MRSA $(8 \mu \mathrm{g} / \mathrm{mL})$, C. albicans (16 $\mu \mathrm{g} / \mathrm{mL})$ and T. rubrum $(32 \mu \mathrm{g} / \mathrm{mL})$ after 15 days of culture. Thus, to maximize antimicrobial metabolites production, malt medium should be used for further cultivation of the Isaria farinosa strain (S88-S89).

\section{EXPERIMENTAL SECTION}

General Experimental Procedures. Optical rotations were measured on an Anton Paar MCP 300 polarimeter (Anton Paar Graz, Austria) in a $100 \mathrm{~mm}$ long, $350-\mu \mathrm{L}$ cell, at $20^{\circ} \mathrm{C}$, with $\mathrm{MeOH}$ used as the solvent. UV spectra were recorded on a Varian Cary $100 \mathrm{UV}$-vis spectrophotometer and measured in a $1 \mathrm{~cm}$ quartz cell at $20^{\circ} \mathrm{C}$. ECD spectra were acquired at $20^{\circ} \mathrm{C}$ on a JASCO J-810 spectropolarimeter. NMR spectra were recorded on a Bruker 500 MHz spectrometer (Bruker, Rheinstetten, Germany). The chemical shifts $(\delta)$ are reported as ppm based on the TMS (tetramethylsilane) signal, and coupling constants $(J)$ are in hertz.

High Resolution ESITOFMS measurements were performed using a Waters Acquity UHPLC system (Waters, Manchester, England) with a column bypass coupled to a Waters Micromass LCT (Low Chromatography Time-of-flight) Premier time-of-flight mass spectrometer equipped with an electrospray interface (ESI).

Flash chromatography was performed on a Grace Reveleris system with dual UV and ELSD (Evaporative Light Scattering Detector) and equipped with a $120 \mathrm{~g}$ or $4 \mathrm{~g} \mathrm{C}_{18}$ column. The flow rate was 50 or $80 \mathrm{~mL} / \mathrm{min}$ for the $120 \mathrm{~g}$ column and $18 \mathrm{~mL} / \mathrm{min}$ for the $4 \mathrm{~g}$ column, and the effluents were monitored at 210 and $270 \mathrm{~nm}$. 
Analytical and preparative HPLC work was conducted using a Gilson system equipped with a 322 pump device, a GX-271 fraction collector, a 171 diode array detector, and a prepELSII electrospray nebulizer detector. The columns used for these experiments included: a Phenomenex Luna $\mathrm{C}_{18} 5 \mu \mathrm{m} 4.6 \times 250 \mathrm{~mm}$ analytical column and a Phenomenex Luna $\mathrm{C}_{18} 5$ $\mu \mathrm{m} 21.2 \times 250 \mathrm{~mm}$ preparative one (Phenomenex, Le Pecq, France). The flow rate was set to 1 or $21 \mathrm{~mL} / \mathrm{min}$, respectively, using a gradient of $\mathrm{H}_{2} \mathrm{O}$ mixed with an increasing proportion of acetonitrile. Both solvents were modified with $0.1 \%$ formic acid. All solvents were HPLC grade, purchased from Sigma-Aldrich (Saint-Quentin-Fallavier, France).

Fungus Material. The fungal strain was isolated by Christian Lechat (ASCOFRANCE) from an unidentified insect larva found under the bark of a dead Carpinus betulus, in France, Deux-Sèvres, Villiers-en-Bois, June 16, 2010 and identified as Isaria farinosa. The strain BSNB-1250 was saved in triplicate at $-80{ }^{\circ} \mathrm{C}$ in $\mathrm{H}_{2} \mathrm{O}$-glycerol (50:50). A sample was submitted for amplification of the nuclear ribosomal internal transcribed spacer region ITS1 that allowed for identification by comparison to the NCBI database. The sequence was registered in the NCBI GenBank database with the accession number MF950892 and the strain was also conserved in the CIRM under number BRFM 1607.

Large-Scale Cultivation on PDA, Extraction and Isolation. The fungal strain was cultivated on PDA (potato dextrose agar) in 390 14-cm Petri dishes at $28{ }^{\circ} \mathrm{C}$ for 15 days. The culture medium containing the mycelium was cut into small pieces and macerated with ethyl acetate (EtOAc) for $24 \mathrm{~h}$. The organic solvent was evaporated to dryness under reduced pressure to yield $4.36 \mathrm{~g}$ of an oily brown-red crude extract.

It was then fractionated by reverse flash chromatography on a $\mathrm{C}_{18}$ column with a 5-minstep gradient of water mixed with an increasing proportion of acetonitrile $(v / v, 95: 5,80: 20$, $60: 40,45: 55,30: 70,15: 85,0: 1$, flow rate $80 \mathrm{~mL} / \mathrm{min}$ ) to generate 3 fractions, $\mathrm{F} 1$ to $\mathrm{F} 3$, 
according to their UV and DEDL profiles. Another step gradient of acetonitrile - methylene chloride ( $v / v, 1: 1$ to $0: 1$, flow rate $80 \mathrm{~mL} / \mathrm{min})$ was conducted to generate 2 additional fractions, F4 and F5. Purification of $1.86 \mathrm{~g}$ of F3 by reverse flash chromatography on a $\mathrm{C}_{18}$ column with a gradient of water - acetonitrile $(v / v, 1: 1$ during 4 min, 1:1 to $35: 65$ during 8 min, 35:65 to 0:1 in $2 \mathrm{~min}$, flow rate $50 \mathrm{~mL} / \mathrm{min}$ ) yielded 15 fractions, F3-1 to F3-15. Another step gradient of acetonitrile - methylene chloride $(v / v, 1: 1$ to $0: 1$, flow rate $50 \mathrm{~mL} / \mathrm{min})$ was conducted to generate an additional fraction, F3-16.

Fractions F3-2 and F3-10 were two pure compounds: respectively compound 2 (87.6 mg, $\left.\mathrm{t}_{\mathrm{R}}=20.0 \mathrm{~min}\right)$ and compound $3\left(58.9 \mathrm{mg}, \mathrm{t}_{\mathrm{R}}=7.4 \mathrm{~min}\right) . \mathrm{F} 3-4(43.3 \mathrm{mg})$ was subjected to preparative HPLC (Luna $\mathrm{C}_{18}$, mobile phase $\mathrm{H}_{2} \mathrm{O}+0.1 \% \mathrm{FA} / \mathrm{CH}_{3} \mathrm{CN}+0.1 \% \mathrm{FA}$, isocratic elution 55:45 during $12 \mathrm{~min}$, flow rate $21 \mathrm{~mL} / \mathrm{min})$ leading to compound $4\left(22.8 \mathrm{mg}, \mathrm{t}_{\mathrm{R}}=9.8\right.$ min). F3-6 (87.7 mg) was subjected to preparative HPLC (Luna $\mathrm{C}_{18}$, mobile phase $\mathrm{H}_{2} \mathrm{O}+$ $0.1 \% \mathrm{FA} / \mathrm{CH}_{3} \mathrm{CN}+0.1 \% \mathrm{FA}$, isocratic elution 45:55 during $12 \mathrm{~min}$, then a linear gradient 45:55 to 0:1 over $12 \mathrm{~min}$, flow rate $21 \mathrm{~mL} / \mathrm{min}$ ) leading to 6 fractions, F3-6A to F3-6F. F3-6A (67.7 mg) was subjected to preparative HPLC (Luna $\mathrm{C}_{18}$, mobile phase $\mathrm{H}_{2} \mathrm{O}+0.1 \%$ $\mathrm{FA} / \mathrm{CH}_{3} \mathrm{CN}+0.1 \% \mathrm{FA}$, isocratic elution $1: 1$ during $25 \mathrm{~min}$, flow rate $21 \mathrm{~mL} / \mathrm{min}$ ) leading to compound $6\left(9.2 \mathrm{mg}, \mathrm{t}_{\mathrm{R}}=21 \mathrm{~min}\right) . \mathrm{F} 3-8(143.1 \mathrm{mg})$ was subjected to reverse flash chromatography on a $\mathrm{C}_{18}$ column with a gradient of water - acetonitrile ( $v / v, 4: 6$ to 2:8 in 20 min, then $0: 1$, flow rate $18 \mathrm{~mL} / \mathrm{min})$ leading to compound $\mathbf{1}\left(61 \mathrm{mg}, \mathrm{t}_{\mathrm{R}}=3.2 \mathrm{~min}\right)$. Dissolution of F3-14 (107.4 mg) in methanol precipitated compound 5 that was isolated by filtration (25.0 $\mathrm{mg})$.

Paecilosetin A (1): yellow solid; $[\alpha]^{20}{ }_{\mathrm{D}}-528(c 0.1, \mathrm{MeOH})$; $\mathrm{CD}(\mathrm{MeOH}) \lambda_{\max }(\Delta \varepsilon) 239(-$ 0.8), 251 (-0.3), 284 (-11.3), 317 (+7.56); UV (MeOH) $\lambda_{\max }(\log \varepsilon) 250(0.57), 287(0.72) ;{ }^{1} \mathrm{H}$ 
and ${ }^{13} \mathrm{C}$ NMR data, see Table 2 and S5 to S10; HRESITOFMS $m / z 374.2334[\mathrm{M}+\mathrm{H}]^{+}$(calcd $^{2}$ for $\mathrm{C}_{22} \mathrm{H}_{32} \mathrm{NO}_{4}, 374.2331$, err. 0.80 ppm).

6'-epi-Paecilosetin B (2): yellow solid; $[\alpha]^{20}{ }_{\mathrm{D}}-304$ (c 0.1, MeOH); $\mathrm{CD}(\mathrm{MeOH}) \lambda_{\max }(\Delta \varepsilon)$ 245 (-2.6), $286(-11.9), 316(+5.6) ; \mathrm{UV}(\mathrm{MeOH}) \lambda_{\max }(\log \varepsilon) 249(0.64), 285(0.81) ;{ }^{1} \mathrm{H}$ and ${ }^{13} \mathrm{C}$ NMR data, see Table 2 and S18 to S23; HRESITOFMS $m / z 374.2327[\mathrm{M}+\mathrm{H}]^{+}$(calcd for $\mathrm{C}_{22} \mathrm{H}_{32} \mathrm{NO}_{4}, 374.2331$, err. -1.06 ppm).

Paecilosetin B (3): yellow solid; $[\alpha]^{20}{ }_{\mathrm{D}}-569(c 0.1, \mathrm{MeOH}) ; \mathrm{CD}(\mathrm{MeOH}) \lambda_{\max }(\Delta \varepsilon) 239(-$ 0.3), $251(-4.0), 284(-15.1), 318(+3.4) ; \mathrm{UV}(\mathrm{MeOH}) \lambda_{\max }(\log \varepsilon) 251(0.65), 286(0.87) ;{ }^{1} \mathrm{H}$ and ${ }^{13} \mathrm{C}$ NMR data, see Table 2 and S27 to S32; HRESITOFMS $m / z 390.2292[\mathrm{M}+\mathrm{H}]^{+}$(calcd for $\mathrm{C}_{22} \mathrm{H}_{32} \mathrm{NO}_{5}, 390.2280$, err. 3.07 ppm).

6'-epi-Paecilosetin B (4): yellow solid; $[\alpha]^{20}{ }_{\mathrm{D}}-290$ (c 0.1, MeOH); $\mathrm{CD}(\mathrm{MeOH}) \lambda_{\max }(\Delta \varepsilon)$ 246 (-2.2), $286(-9.4), 315(+4.7) ; \mathrm{UV}(\mathrm{MeOH}) \lambda_{\max }(\log \varepsilon) 249(0.77), 285(0.91) ;{ }^{1} \mathrm{H}$ and ${ }^{13} \mathrm{C}$ NMR data, see Table 2 and S36 to S41; HRESITOFMS $m / z 390.2280[\mathrm{M}+\mathrm{H}]^{+}$(calcd for $\mathrm{C}_{22} \mathrm{H}_{32} \mathrm{NO}_{5}, 390.2280$, err. 0.00 ppm).

Paecilosetin C (5): colorless needle $\left(\mathrm{CH}_{2} \mathrm{Cl}_{2}\right) ;[\alpha]^{20}{ }_{\mathrm{D}}-363($ c $0.1, \mathrm{MeOH}) ; \mathrm{CD}(\mathrm{MeOH})$ $\lambda_{\max }(\Delta \varepsilon) 242$ (-5.8), 269 (-13.2), $295(-3.8), 305(-4.39), 338(+3.2) ; \mathrm{UV}(\mathrm{MeOH}) \lambda_{\max }(\log \varepsilon)$ 274 (0.89); ${ }^{1} \mathrm{H}$ and ${ }^{13} \mathrm{C}$ NMR data, see Table 2 and S45 to S51; HRESITOFMS $\mathrm{m} / \mathrm{z} 356.2234$ $[\mathrm{M}+\mathrm{H}]^{+}$(calcd for $\mathrm{C}_{22} \mathrm{H}_{30} \mathrm{NO}_{3}, 356.2226$, err. 2.24 ppm).

Paecilosetin D (6): pale pink solid; $[\alpha]^{20}{ }_{\mathrm{D}}-320(c 0.1, \mathrm{MeOH}) ; \mathrm{CD}(\mathrm{MeOH}) \lambda_{\max }(\Delta \varepsilon) 241$ (-4.3), $271(-10.8), 299(-3.2), 337(+2.4)$; $\mathrm{UV}(\mathrm{MeOH}) \lambda_{\max }(\log \varepsilon) 275(0.81) ;{ }^{1} \mathrm{H}$ and ${ }^{13} \mathrm{C}$ NMR data, see Table 2 and S55 to S61; HRESITOFMS $m / z 372.2169[\mathrm{M}+\mathrm{H}]^{+}$(calcd for $\mathrm{C}_{22} \mathrm{H}_{30} \mathrm{NO}_{4}, 372.2175$, err. $1.61 \mathrm{ppm}$ ). 
OSMAC Cultures and Extraction. I. farinosa was cultivated under several culture conditions: PDA, Czapek, malt extract, PDA with yeast extract (3 and 10 g/L), and PDA with $\mathrm{NaCl}(3$ and $10 \mathrm{~g} / \mathrm{L})$ on 10 Petri dishes (diameter $10 \mathrm{~cm})$ for 15 days. The fungus on the culture media was macerated with $250 \mathrm{~mL}$ EtOAc for $24 \mathrm{~h}$ on a shaking platform, then filtered and washed twice with $\mathrm{H}_{2} \mathrm{O}$. Solvent evaporation yielded: $18.4 \mathrm{mg}$ extract on PDA medium, $5.3 \mathrm{mg}$ on Czapek medium, $32.3 \mathrm{mg}$ on malt extract, $34.2 \mathrm{mg}$ on PDA with $3 \mathrm{~g} / \mathrm{L}$ yeast, $28.4 \mathrm{mg}$ on PDA medium with $10 \mathrm{~g} / \mathrm{L}$ yeast, $28.2 \mathrm{mg}$ on PDA medium with $3 \mathrm{~g} / \mathrm{L}$ $\mathrm{NaCl}$, and $36.1 \mathrm{mg}$ on PDA medium with $10 \mathrm{~g} / \mathrm{L} \mathrm{NaCl}$. Sterile culture media were also extracted in the same conditions for subtraction of culture media peaks in the metabolomic analysis.

Mosher Ester Analysis of 1, 3 and 4. In an NMR sample tube (3 mm diameter) $1 \mathrm{mg}$ of dimethylaminopyridine (DMAP) was added to $1.0 \mathrm{mg}(8.2 \mu \mathrm{mol})$ of compound $\mathbf{1}, \mathbf{3}$ or $\mathbf{4}$. Nine microliters of pyridine- $d_{5}$ and $600 \mu \mathrm{L}$ of $\mathrm{CDCl}_{3}$ were added to this mixture. Then, 13.5 $\mu \mathrm{L}$ of $(R)$-MTPA chloride $(72 \mu \mathrm{mol})$ was added. The resultant reaction mixture was stirred at RT for 120 min to produce $(S)$-MTPA esters 1a, 3a and 4a. The identical procedure was carried out to obtain the (R)-MTPA ester $\mathbf{1 b}, \mathbf{3 b}$ and $\mathbf{4 b}$ from $(S)$-MTPA chloride.

Antimicrobial Assays. The ATCC strains were purchased from the Institut Pasteur and a clinical isolate was provided by Phillipe Loiseau (University Paris-Saclay, Châtenay-Malabry, France). The strains used in this study were: Candida albicans ATCC10231, Escherichia coli ATCC25922, Staphylococcus aureus ATCC29213, methicillin-resistant Staphylococcus aureus ATCC33591 and Trichophyton rubrum SNB-TR1. Extracts, fractions and pure compounds were tested according to the reference protocol of the European Committee on Antimicrobial Susceptibility Testing (EUCAST, http://www.eucast.org, 11 April 2016) ${ }^{34}$. The standard microdilution test as described by the Clinical and Laboratory Standards Institute guidelines (M7, M27 and M38) ${ }^{35-37}$ was used to determine minimal inhibition concentrations 
(MIC) against dermatophyte fungi, bacteria, and yeasts. Crude extracts and pure compounds were tested at concentrations ranging from 256 to $0.5 \mu \mathrm{g} / \mathrm{mL}$. The microplates were incubated at $35^{\circ} \mathrm{C}$. MIC values were obtained after $24 \mathrm{~h}$ for bacteria, $48 \mathrm{~h}$ for yeasts and 5 days for other fungi. The MIC values reported refer to the lowest concentration preventing visible growth in the wells. All assays were conducted in duplicate.

Cell Culture and Proliferation Assay. The MRC-5 cell line derived from normal lung tissue was obtained from the American Type Culture Collection (Rockville, MD, USA) and it was cultured according to the supplier's instructions. Human MRC-5 cells were grown in DMEM supplemented with $10 \%$ fetal calf serum (FCS) and 1\% glutamine. ell line was maintained at $37{ }^{\circ} \mathrm{C}$ in a humidified atmosphere containing $5 \% \mathrm{CO}_{2}$. Cell viability was determined by a luminescent assay according to the manufacturer's instructions (Promega, Madison, WI, USA). For $\mathrm{IC}_{50}$ determination, the cells were seeded in 96 -well plates $\left(3 \times 10^{3}\right.$ cells/well) containing $100 \mu \mathrm{L}$ of growth medium. After $24 \mathrm{~h}$ of culture, the cells were treated with the tested compounds at 10 different final concentrations. Each concentration was obtained from serial dilutions in culture medium starting from the stock solution. Control cells were treated with the vehicle. Experiments were performed in triplicate. After $72 \mathrm{~h}$ of incubation, $100 \mu \mathrm{L}$ of CellTiter Glo Reagent was added for 15 min before recording the luminescence with a spectrophotometric plate reader PolarStar Omega (BMG LabTech). The dose-response curves were plotted with Graph Prism software and the $\mathrm{IC}_{50}$ values were calculated from the polynomial curves (four or five-parameter logistic equations) using the Graph Prism software.

\section{Data Dependent LC ESI HRMS² Analysis for Global Network. Chromatographic} separation was performed using a Waters Acquity UHPLC system interfaced to a Q-Exactive Focus mass spectrometer (Thermo Scientific, Bremen, Germany), using a heated electrospray ionization (HESI-II) source. Thermo Scientific Xcalibur 3.1 software was used for instrument 
control and data analysis. The LC conditions were as follows: column, Waters BEH (Ethylene Bridget Hybrid) $\mathrm{C}_{18} 50 \times 2.1 \mathrm{~mm}, 1.7 \mu \mathrm{m}$; mobile phase, (A) water with $0.1 \%$ formic acid; (B) acetonitrile with $0.1 \%$ formic acid; flow rate, $600 \mu \mathrm{L} / \mathrm{min}$; injection volume, $1 \mu \mathrm{L}$; gradient, linear gradient of $2-100 \%$ B over 6 min and isocratic at $100 \%$ B for $0.6 \mathrm{~min}$. An Acquity UPLC photodiode array detector was used to acquire the PDA spectra, which were collected in the $210-450 \mathrm{~nm}$ range. In the positive ion mode, the di-isooctyl phthalate $\mathrm{C}_{24} \mathrm{H}_{38} \mathrm{O}_{4}[\mathrm{M}+\mathrm{H}]^{+}$ion $(\mathrm{m} / z$ 391.28429) was used as the internal lock mass. The optimized HESI-II parameters were as follows: source voltage, $4.0 \mathrm{kV}$ (pos); sheath gas flow rate $\left(\mathrm{N}_{2}\right)$, 55 units; auxiliary gas flow rate, 15 units; spare gas flow rate, 3.0; capillary temperature, $275.00{ }^{\circ} \mathrm{C}$ (pos), S-Lens RF Level, 45 . The mass analyzer was calibrated using a mixture of caffeine, methionine-arginine-phenylalanine-alanine-acetate (MRFA), sodium dodecyl sulfate, sodium taurocholate, and Ultramark 1621 in an acetonitrile/methanol/water solution containing $1 \%$ acid formic acid by direct injection. The data-dependent MS/MS events were performed on the three most intense ions detected in the full MS scans (Top 3 experiment). The MS/MS isolation window width was $1 \mathrm{Da}$, and the stepped normalized collision energy (NCE) was set to 15,30 and 45 units. In the data-dependent MS/MS experiments, full scans were acquired at a resolution of 35,000 FWHM (at $\mathrm{m} / \mathrm{z} 200$ ) and MS/MS scans were acquired at 17,500 FWHM, both with an automatically determined maximum injection time of $50 \mathrm{~ms}$. After being acquired in a MS/MS scan, the parent ions were placed on the dynamic exclusion list for $2.0 \mathrm{~s}$. AGC target: 1E6 (for full MS), 5E4 (for MS2) and 1E4 (minimum target).

\section{Data Dependent LC ESI HRMS ${ }^{2}$ Analysis for the OSMAC Network. Metabolome} profiling was conducted with a Thermo UHPLC-HRMS system. Analyse of each extract (1.0 $\mu \mathrm{L}$ injected, $2 \mu \mathrm{g}$ on the column) was performed in electrospray positive ionization mode in the 133.4-2000 Da range in centroid mode. The mass detector was an Orbitrap MS/MS FT QExactive focus mass spectrometer. The analysis was conducted in FullMS data dependent 
$\mathrm{MS}^{2}$ mode. In FullMS, the resolution was set to 70,000 and the AGC target was $3.10^{6}$. In $\mathrm{MS}^{2}$, the resolution was 17,500 , AGC target $10^{5}$, isolation window $0.4 \mathrm{Da}$, normalized collision energy 30, with 20 s dynamic exclusion. The UHPLC column was a Phenomenex Luna Omega polar $\mathrm{C}_{18} 150 \times 2.1 \mathrm{~nm}, 1.6 \mu \mathrm{m}$. The column temperature was set to $42^{\circ} \mathrm{C}$, and the flow rate was $0.5 \mathrm{~mL} / \mathrm{min}$. The solvent system was a mixture of water with increasing proportions of acetonitrile, both solvents modified with $0.1 \%$ formic acid.

MZmine 2 Data Preprocessing Parameters for Global Network. Raw files were converted into mzXML (mass spectrometry data format) files using the MSConvert software. Then, mzXML files were processed using MZmine 2.38. ${ }^{8,26}$ Mass detection was carried out with a centroid mass detector with the noise level set to 1.0E7 for the MS1 level and 1.0E4 for the MS2 level set to all. The ADAP (Automated Data Analysis Pipeline) chromatogram builder $^{38}$ was achieved using a minimum group size of scans of 4, a minimum group intensity threshold of 3000, a minimum highest intensity of 3000 and a $m / z$ tolerance of 0.002 or 10.0 ppm. The wavelets (ADAP) algorithm was used for the chromatogram deconvolution with the following settings: $\mathrm{S} / \mathrm{N}$ threshold of 5 , an intensity window $\mathrm{SN}$, a minimum feature height of 3000 , a coefficient area threshold of 20 , a peak duration range between 0 and 1 and an RT wavelet range between 0 and 0.02 . Chromatograms were deisotoped using the isotopic peaks grouper algorithm with an $\mathrm{m} / z$ tolerance of $0.004(15 \mathrm{ppm})$, RT tolerance of 0.2 (absolute), maximum charge of 3 and the representative isotope used was the most intense. Peak alignment was performed using the join aligner method: $\mathrm{m} / \mathrm{z}$ tolerance of 0.003 or $10 \mathrm{ppm}$, weight for $m / z$ of 1.00 , RT tolerance of $0.3 \mathrm{~min}$, weight for RT of 1.00 . The peak list was gap filled with the peak finder method multithreaded with intensity tolerance of $30.00, \mathrm{~m} / \mathrm{z}$ tolerance of $0.003(10 \mathrm{ppm})$ and 0.20 for RT tolerance.

MZmine 2 Data Preprocessing Parameters for the OSMAC Network. Raw files were converted into mzXML (mass spectrometry data format) files using the MSConvert software. 
Then, mzXML files were processed using MZmine $2.38 .{ }^{8,26}$ Mass detection was carried out with a centroid mass detector with the noise level set to 1.8E7 for the MS1 level and 1.0E4 for MS2 level set to all. The ADAP (Automated Data Analysis Pipeline) chromatogram builder ${ }^{38}$ was achieved using a minimum group size of scans of 4 , a minimum group intensity threshold of 2.6E7, a minimum highest intensity of $2.6 \mathrm{E} 7$ and a $\mathrm{m} / \mathrm{z}$ tolerance of 0.005 or $20.0 \mathrm{ppm}$. The wavelets (ADAP) algorithm was used for the chromatogram deconvolution with the following settings: S/N threshold of 10 , an intensity window $\mathrm{SN}$, a minimum feature height of $2.6 \mathrm{E} 7$, a coefficient area threshold of 20, a peak duration range between 0 and 1 and an RT wavelet range between 0 and 0.02 . Chromatograms were deisotoped using the isotopic peaks grouper algorithm with an $\mathrm{m} / \mathrm{z}$ tolerance of 0.004 (15 ppm), RT tolerance of 0.2 (absolute), maximum charge of 3 and the representative isotope used was the most intense. Peak alignment was performed using the join aligner method: $\mathrm{m} / \mathrm{z}$ tolerance of 0.003 or $10 \mathrm{ppm}$, weight for $\mathrm{m} / \mathrm{z}$ of 1.00, RT tolerance of $0.3 \mathrm{~min}$, weight for RT of 1.00 .

Global and OSMAC Molecular Network Analysis. After preprocessing the UHPLCHRMS/MS data with MZmine 2.38, the output .mgf file was processed with the MetGem software version 1.2.2 $\mathrm{RC} 3^{9}$ to give a network containing nodes distributed in clusters. Networks were generated using the following parameters: $\mathrm{m} / \mathrm{z}$ tolerance set to 0.01 , Minimum Matched Peaks set to 4, topK set to 10, Minimal Cosine score Value of 0.65 and Max. Connected Component Size of 400. Then, the associated CSV file was loaded. For the mapping process, the relative quantification of each ion was represented by pie chartdiagrams for which the proportions were based on the respective areas of the corresponding extracted ion chromatograph areas (XIC). Then, the analogues of the spectra in the network were searched in the available spectral libraries. The library spectra were filtered in the same manner as the input data. All of the matches between the network spectra and library spectra were required to have a score above 0.6 and at least 4 matched peaks. The $m / z$ tolerance for 
the analogues search was set to 100 . T-SNE visualization was generated using the following parameters: at least 1 cosine score above 0.60 ; number of iterations: 1000 ; perplexity: 6 ; learning rate: 200; early exaggeration: 12; using Barnes-hut approximation with an angle of 0.5 .

X-ray structure determination of compound 5. Crystals suitable for single-crystal X-ray analysis were obtained from $\mathrm{MeOH}$ solution evaporation at $5{ }^{\circ} \mathrm{C}$. X-ray crystallographic data were collected on a Rigaku Rapid II (IP area detector system) diffractometer equipped with a rotating anode mm007 $\mathrm{HF}$ generator and Osmic mirrors $(\mathrm{Cu} \mathrm{K} \alpha$ radiation, $\lambda=1.54187 \AA)$ using $\omega$-scans. Samples were irradiated at a low temperature in a continuous $\mathrm{LN}_{2}$ stream at $235 \mathrm{~K}$. Crystallographic data for compound 5: $\mathrm{C}_{22} \mathrm{H}_{29} \mathrm{NO}_{3}, \mathrm{M}=355.46,0.35 \times 0.075 \times 0.03$ mm, orthorhombic, P212121, a = 13.5830(5) $\AA, \mathrm{b}=15.4136(5) \AA, \mathrm{c}=19.6284(14) \AA, \mathrm{V}=$ 4109.5(4) A3, $\mathrm{Z}=8$, Dcalc $=1.149 \mathrm{~g} / \mathrm{cm}^{3}, \mu(\mathrm{CuK} \alpha)=0.600 \mathrm{~mm}-1, \mathrm{~T}=235.15 \mathrm{~K}, 21525$ reflections measured $\left(13.036^{\circ} \leq 2 \Theta \leq 140.024^{\circ}\right), 7402$ unique $(\operatorname{Rint}=0.0409$, Rsigma $=$ $0.0995)$ which were used in all calculations. The final R1 was $0.0480(\mathrm{I}>2 \sigma(\mathrm{I}))$ and wR2 was 0.1131 (all data). $\mathrm{S}=1.040$, Flack parameter $=-0.07(10)$. Crystallographic data for this structure have been deposited in the Cambridge Crystallographic Data Centre database (deposition number CCDC 1985120). Copies of the data can be obtained free of charge from the CCDC at www.ccdc.cam.ac.uk.

\section{ASSOCIATED CONTENT}

\section{Supporting Information.}

The supporting information is available free of charge on the ACS Publications website.

Full global and OSMAC molecular networks (PDF)

NMR, MS and ECD spectra of all compounds (PDF)

X-ray data of compound 5 (PDF, CIF) 


\section{AUTHOR INFORMATION}

\section{Corresponding Author}

*Tel: +33 1698236 79. E-mail: veronique.eparvier@cnrs.fr.

\section{ORCID}

Orianne Brel: 0000-0002-4996-2580

Isabelle Dusfour: 0000-0002-5265-8432

Véronique Eparvier: 0000-0002-2954-0866

Christian Lechat: 0000-0002-8077-0181

Marceau Levasseur: 0000-0002-2735-5501

Marc Litaudon: 0000-0002-0877-8234

Léonie Pélissier: 0000-0003-0784-7194

Didier Stien: 0000-0002-9950-5361

Elsa Van-Elslande: 0000-0003-2202-2174

Jean-Luc Wolfender: 0000-0002-0125-952X

\section{Author Contributions}

The manuscript was written through contributions of all authors. All authors have given approval to the final version of the manuscript. These authors contributed equally.

\section{Notes}

The authors declare no competing financial interest.

\section{ACKNOWLEDGMENTS}

This work was supported by an "Investissement d'Avenir" grant managed by Agence Nationale de la Recherche (CEBA, ref. ANR-10-LABX-25-01). We are grateful to JeanFrançois Gallard from ICSN for his help in carrying out the NMR experiment and Marine 
Bourceau for her help on the fractionation. The authors are very grateful to Christian Lechat for the transfer of the biological material from the CIRM collection voucher conserved under the number BRFM 1607.

\section{REFERENCES}

(1) World Health Organization. Antibiotic resistance https://www.who.int/news-room/factsheets/detail/antibiotic-resistance (accessed Feb 14, 2020).

(2) Newman, D. J.; Cragg, G. M. J. Nat. Prod. 2016, 79, 629-661.

(3) Offret, C.; Desriac, F.; Le Chevalier, P.; Mounier, J.; Jégou, C.; Fleury, Y. Mar. Drugs 2016, 14, 129.

(4) Gunatilaka, A. A. L. J. Nat. Prod. 2006, 69, 509-526.

(5) Wilson, Z. E.; Brimble, M. A. Nat. Prod. Rep. 2009, 26, 44-71.

(6) Bode, H. B. Curr. Opin. Chem. Biol. 2009, 13, 224-230.

(7) Wang, M.; Carver, J. J.; Phelan, V. V.; Sanchez, L. M.; Garg, N.; Peng, Y.; Nguyen, D. D.; Watrous, J.; Kapono, C. A.; Luzzatto-Knaan, T.; Porto, C.; Bouslimani, A.; Melnik, A. V.; Meehan, M. J.; Liu, W. T.; Crüsemann, M.; Boudreau, P. D.; Esquenazi, E.; Sandoval-Calderón, M.; Kersten, R. D.; Pace, L. A.; Quinn, R. A.; Duncan, K. R.; Hsu, C. C.; Floros, D. J.; Gavilan, R. G.; Kleigrewe, K.; Northen, T.; Dutton, R. J.; Parrot, D.; Carlson, E. E.; Aigle, B.; Michelsen, C. F.; Jelsbak, L.; Sohlenkamp, C.; Pevzner, P.; Edlund, A.; McLean, J.; Piel, J.; Murphy, B. T.; Gerwick, L.; Liaw, C. C.; Yang, Y. L.; Humpf, H. U.; Maansson, M.; Keyzers, R. A.; Sims, A. C.; Johnson, A. R.; Sidebottom, A. M.; Sedio, B. E.; Klitgaard, A.; Larson, C. B.; Boya, C. A. P.; TorresMendoza, D.; Gonzalez, D. J.; Silva, D. B.; Marques, L. M.; Demarque, D. P.; Pociute, 
E.; O’Neill, E. C.; Briand, E.; Helfrich, E. J. N.; Granatosky, E. A.; Glukhov, E.; Ryffel, F.; Houson, H.; Mohimani, H.; Kharbush, J. J.; Zeng, Y.; Vorholt, J. A.; Kurita, K. L.; Charusanti, P.; McPhail, K. L.; Nielsen, K. F.; Vuong, L.; Elfeki, M.; Traxler, M. F.; Engene, N.; Koyama, N.; Vining, O. B.; Baric, R.; Silva, R. R.; Mascuch, S. J.; Tomasi, S.; Jenkins, S.; Macherla, V.; Hoffman, T.; Agarwal, V.; Williams, P. G.; Dai, J.; Neupane, R.; Gurr, J.; Rodríguez, A. M. C.; Lamsa, A.; Zhang, C.; Dorrestein, K.; Duggan, B. M.; Almaliti, J.; Allard, P. M.; Phapale, P.; Nothias, L. F.; Alexandrov, T.; Litaudon, M.; Wolfender, J. L.; Kyle, J. E.; Metz, T. O.; Peryea, T.; Nguyen, D. T.; VanLeer, D.; Shinn, P.; Jadhav, A.; Müller, R.; Waters, K. M.; Shi, W.; Liu, X.; Zhang, L.; Knight, R.; Jensen, P. R.; Palsson, B.; Pogliano, K.; Linington, R. G.; Gutiérrez, M.; Lopes, N. P.; Gerwick, W. H.; Moore, B. S.; Dorrestein, P. C.; Bandeira, N. Nat. Biotechnol. 2016, 34, 828-837.

(8) Olivon, F.; Grelier, G.; Roussi, F.; Litaudon, M.; Touboul, D. Anal. Chem. 2017, 89, 7836-7840.

(9) Olivon, F.; Elie, N.; Grelier, G.; Roussi, F.; Litaudon, M.; Touboul, D. Anal. Chem. 2018, 90, 13900-13908.

(10) Touré, S.; Desrat, S.; Pellissier, L.; Allard, P. M.; Wolfender, J. L.; Dusfour, I.; Stien, D.; Eparvier, V. Int. J. Mol. Sci. 2019, 20, 1083.

(11) Wolfender, J. L.; Nuzillard, J. M.; Van Der Hooft, J. J. J.; Renault, J. H.; Bertrand, S. Anal. Chem. 2019, 91, 704-742.

(12) Zimmermann, G. Biocontrol Sci. Technol. 2008, 18, 865-901.

(13) Cheng, Y.; Schneider, B.; Riese, U.; Schubert, B.; Li, Z.; Hamburger, M. J. Nat. Prod. 2004, 67, 1854-1858. 
(14) Lang, G.; Blunt, J. W.; Cummings, N. J.; Cole, A. L. J.; Munro, M. H. G. J. Nat. Prod. 2005, 68, 810-811.

(15) Zhang, Y.; Liu, S.; Liu, H.; Liu, X.; Che, Y. J. Nat. Prod. 2009, 72, 1364-1367.

(16) Sakakura, A.; Suzuki, K.; Katsuzaki, H.; Komiya, T.; Imamura, T.; Aizono, Y.; Imai, K. Tetrahedron Lett. 2005, 46, 9057-9059.

(17) VanderMolen, K. M.; Raja, H. A.; El-Elimat, T.; Oberlies, N. H. AMB Express 2013, 3, 71.

(18) Marmann, A.; Aly, A. H.; Lin, W.; Wang, B.; Proksch, P. Mar. Drugs 2014, 12, $1043-$ 1065.

(19) Pettit, R. K. Microb. Biotechnol. 2011, 4, 471-478.

(20) Nett, M.; Ikeda, H.; Moore, B. S. Nat. Prod. Rep. 2009, 26, 1362-1384.

(21) Bertrand, S.; Schumpp, O.; Bohni, N.; Monod, M.; Gindro, K.; Wolfender, J.-L. J. Nat. Prod. 2013, 76, 1157-1165.

(22) Hewage, R. T.; Aree, T.; Mahidol, C.; Ruchirawat, S.; Kittakoop, P. Phytochemistry 2014, 108, 87-94.

(23) Rutledge, P. J.; Challis, G. L. Nat. Rev. Microbiol. 2015, 13, 509-523.

(24) Bode, H. B.; Bethe, B.; Höfs, R.; Zeeck, A. ChemBioChem 2002, 3, 619-627.

(25) Nirma, C.; Eparvier, V.; Stien, D. J. Antibiot. (Tokyo). 2015, 68, 586-590.

(26) Pluskal, T.; Castillo, S.; Villar-Briones, A.; Orešič, M. BMC Bioinformatics 2010, 11, 395. 
(27) Olivon, F.; Allard, P. M.; Koval, A.; Righi, D.; Genta-Jouve, G.; Neyts, J.; Apel, C.; Pannecouque, C.; Nothias, L. F.; Cachet, X.; Marcourt, L.; Roussi, F.; Katanaev, V. L.; Touboul, D.; Wolfender, J. L.; Litaudon, M. ACS Chem. Biol. 2017, 12, 2644-2651.

(28) Phillips, N. J.; Goodwin, J. T.; Fraiman, A.; Cole, R. J.; Lynn, D. G. J. Am. Chem. Soc. 1989, $111,8223-8231$.

(29) Kauhl, U.; Andernach, L.; Weck, S.; Sandjo, L.P.; Jacob, S.; Thines, E.; Opatz, T. J. Org. Chem. 2016, 81, 215-228.

(30) Kauhl, U.; Andernach, L.; Opatz, T. J. Org. Chem. 2018, 83, 15170-15177.

(31) Halecker, S.; Surup, F.; Kuhnert, E.; Mohr, K.; Brock, N. L.; Dickschat, J. S.; Junker, C.; Schulz, B.; Stadler, M. Phytochemistry 2014, 100, 86-91.

(32) Marfori, E. C.; Kajiyama, S.; Fukusaki, E. I.; Kobayashi, A. Z. Naturforsch., C: J. Biosci. 2002, 57, 465-470.

(33) Hoye, T. R.; Jeffrey, C. S.; Shao, F. Nat. Protoc. 2007, 2, 2451-2458.

(34) European Committee on Antimicrobial Susceptibility Testing : EUCAST. https://eucast.org/ (accessed Apr 11, 2016).

(35) Clinical and Laboratory Standards. Methods for Dilution Antimicrobial Susceptibility Tests for Bacteria That Grow Aerobically - M07, 11th ed.; Wayne, PA, USA, 2018.

(36) Clinical and Laboratory Standards. Reference Method for Broth Dilution Antifungal Susceptibility Testing of Yeasts - M27, 4th ed.; Wayne, PA, USA, 2017.

(37) Clinical and Laboratory Standards. Reference Method for Broth Dilution Antifungal Susceptibility Testing of Filamentous Fungi - M38, 3rd ed.; Wayne, PA, USA, 2017. 
(38) Myers, O. D.; Sumner, S. J.; Li, S.; Barnes, S.; Du, X. Anal. Chem. 2017, 89, 86968703. 
FOR TABLE OF CONTENTS ONLY

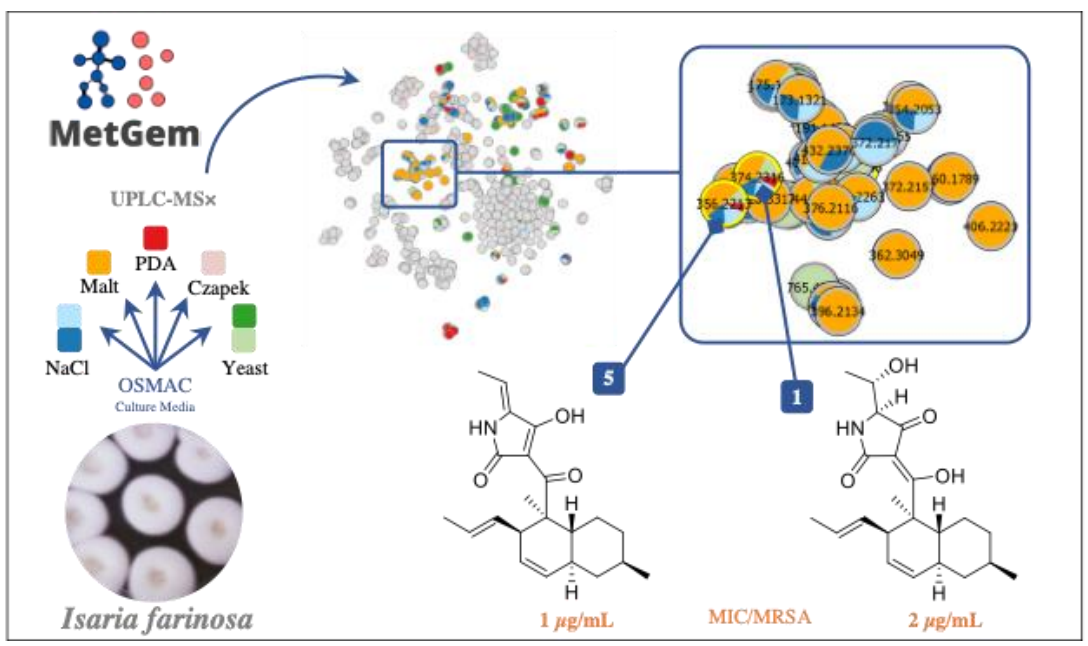

